\title{
Analysis of Marketing Margins and Farmers' Shares on Corn in Sigi Regency, Central Sulawesi, Indonesia
}

\author{
Heni Sulistyawati Purwaning Rahayu*, Mardiana Dewi and Muhammad Abid \\ Assessment Institute for Agricultural Technology for Central Sulawesi, Indonesia \\ ${ }^{*}$ Corresponding author: sulistyawati79@gmail.com
}

\begin{abstract}
An increase in corn productivity is not always followed by an increase in farmer income and welfare. The sustainability of farms must be supported by its economic viability including the marketing aspect. This study aimed to analyze the marketing of corn in Sigi Regency, Central Sulawesi Province. This research applied qualitative and quantitative methods. Marketing channel and marketing margin were analyzed descriptively, while farmer share was analyzed quantitatively using variance analysis (ANOVA). The results have shown three types of corn marketing channels, namely: 1) channel I, consisting of farmers-consumers, 2) channel II, covering farmers-collectors, traders-retailers and traders-consumers and 3) channel III, including farmers-collectors and traders- feed industries. Channel II has the highest marketing margin, followed by channel III and I, respectively. The intermediaries determine marketing costs that affect marketing margin and farmers' shares. Channel I has the highest farmers' shares, followed by channel III and channel II, respectively. The results of the significant difference test have revealed a difference in farmers' shares in the marketing channels; and hence, the choice of marketing channel significantly determines the farmers' shares. Therefore, farmers should shorten the marketing chain and strengthen their bargaining position by activating groups. Meanwhile, the government can play an active role so that farmers can have an access to strengthening capital and marketing.
\end{abstract}

Keywords: fair distribution; farmer welfare; food supply chain

Cite this as: Rahayu, H. S. P., Dewi, M., \& Abid, M. (2021). Analysis of Marketing Margins and Farmers' Shares on Corn in Sigi Regency, Central Sulawesi, Indonesia. Caraka Tani: Journal of Sustainable Agriculture, 36(2), 355-364. doi: http://dx.doi.org/10.20961/carakatani.v36i2.49409

\section{INTRODUCTION}

The corn commodity has a very important role in the national economy in addition to other main food commodities, such as rice. Apart from being a food ingredient, corn is the main ingredient in the animal feed industry that has no perfect substitute especially for monogastric livestock (Suarni and Yasin, 2011). Thus, the demand for corn is increasing in line with the growth of the population. The contribution of the commodity is not only for the national economy but also specifically for farmers.
Considering the importance of corn to the economy, the development of this commodity is expected to be sustainable.

Sustainability is a function of a system and the intervention, as well as social, economic and technical dimensions that are carried out to fight negative pressures, highlighting the resilience of the system (Martínez-Castillo, 2016). Sustainability in the farming system means the capability of maintaining its productivity and usefulness to society continuously, which covers resource-conserving, socially supportive, commercially competitive and environmentally

\footnotetext{
* Received for publication March 17, 2021

Accepted after corrections July 26, 2021
} 
sound (Hodge, 1993 in Rigby and Caceres, 1997). Sustainable agriculture considers some aspects, such as satisfying human food, enhancing environmental quality and relying on the natural resource of the agricultural economy. Moreover, sustainable agriculture makes the most efficient use of non-renewable sources, sustains the economic viability of farm operations and enhances the quality of life for the farmer. Furthermore, one research supporting the development of sustainable agriculture has revealed that recently, consumers have a strong preference for sustainability indicators associated with food safety and these preferences are intense to population and consumption characteristics (Okpiaifo et al., 2020).

Economic viability on farms relates to the whole agribusiness system, including the marketing aspect. The current demand for corn continues to increase, which is directly proportional to population growth as a result of increased food demand and consumption of animal protein because corn is the main source of feed. Kalangi and Umboh (2017) state that the market price of corn becomes a benchmark for the price of national feed, which in turn will affect fluctuations in the price of food sources of protein, such as meat and eggs. Given the important role of the corn commodity, the Indonesian government is trying to be selfsufficient in corn by increasing corn production and productivity. Sigi Regency, Central Sulawesi Province, is currently one of the regencies that are actively developing corn.

Apart from the trend of relatively rising market prices as the market potential, the natural potentials such as rainfall, soil and humidity of Sigi Regency are also very suitable for corn production. Another factor that affects the increase of corn production in Sigi Regency is the existence of a natural disaster in 2018 that damaged the farmers' irrigation installations; and therefore, shifting the types of rice commodities to the commodities that are more tolerant of water shortages, including corn, is recommended. Supported by natural potential, market and government programs, corn production and productivity in Sigi Regency have continued to increase over the last five years (Rahayu and Suwitra, 2018). Corn production in Sigi Regency in 2018 was 52,022 tons, the third-highest after Poso 77,515 tons and Buol 56,102 tons (BPS, 2019).
Moreover, it is expected that the increase in production and productivity of corn will lead to improving the welfare of farmers. However, an increase in production does not automatically increase farmers' income and welfare. Various aspects affect farmers' welfare, which is mostly market aspects such as commodity prices and the flow of goods from producers to consumers. Effective marketing of corn has influenced the market efficiency which determines the income of farmers (Pamungkas et al., 2013). In addition, there were problems in the long supply chain and high logistics costs which made the purchase cost of corn more expensive. In the end, the price of corn received by farmers is cheaper, which becomes a challenge for improving farmers' welfare (Sulaiman et al., 2017). An important factor in smoothing the flow of goods from producers to consumers is the correct selection of marketing channels. The government should develop more production centers for corn with efficient marketing.

Increasing the efficiency of marketing agricultural products will contribute to increasing food security and the welfare of farmers in Indonesia (Anindita et al., 2013). Inefficient marketing channels will occur if the marketing costs are greater and the value of the marketed products is smaller. Rosmawati (2011) has added that marketing can be said to be efficient if it can deliver the results from producers to consumers at the lowest possible costs and make a fair share of the total price paid by the end consumer from all parties who participate in all production activities and product marketing. Lack of precise marketing channels can lead to high marketing costs. The marketing of corn in the Sigi Regency has not been widely studied by related parties. Therefore, this study aims to determine the analysis of corn marketing in Sigi Regency to recommend policies in the field of corn marketing in Sigi Regency, Central Sulawesi Province.

\section{MATERIALS AND METHOD}

\section{Objective, time and location of research}

The study aims to determine the analysis of corn marketing in Sigi Regency to recommend policies in the field of corn marketing in Sigi Regency, Central Sulawesi Province, Indonesia. The study area was Sigi Regency, Central 
Sulawesi Province. Specifically, the research was conducted in Gumbasa and West Dolo Sub-districts with the consideration that these locations are the centers of corn production in the Sigi Regency. Data collection was carried out for three months, from October to December 2019.

\section{Data and data sources}

The study consists of primary and secondary data. Primary data were obtained from interviews with respondents involving in the production and marketing of corn. The data collected includes information on production, selling price and marketing channels. The study used the purposive sampling method to select the farmers in the corn development areas of the Sigi Regency. The development program covered the Gumbasa Sub-district and Dolo Barat Sub-district, which are both the centers of corn in the Sigi Regency. Farmers in the two sub-district are consistently planting corn throughout the year. Farmer groups in the two areas joining the corn development program were selected. Afterward, the active members were randomly chosen as respondents. Purposively, the flow of corn sales was traced to select respondents involving in the marketing chain. These respondents were farmers, collector traders, field extension officers (PPL), wholesalers and feed industry in Palu City. The total number of respondents was 60 farmers, four field extension officers, 12 respondents of the marketing chain. The details of respondents' determination are presented in Figure 1.

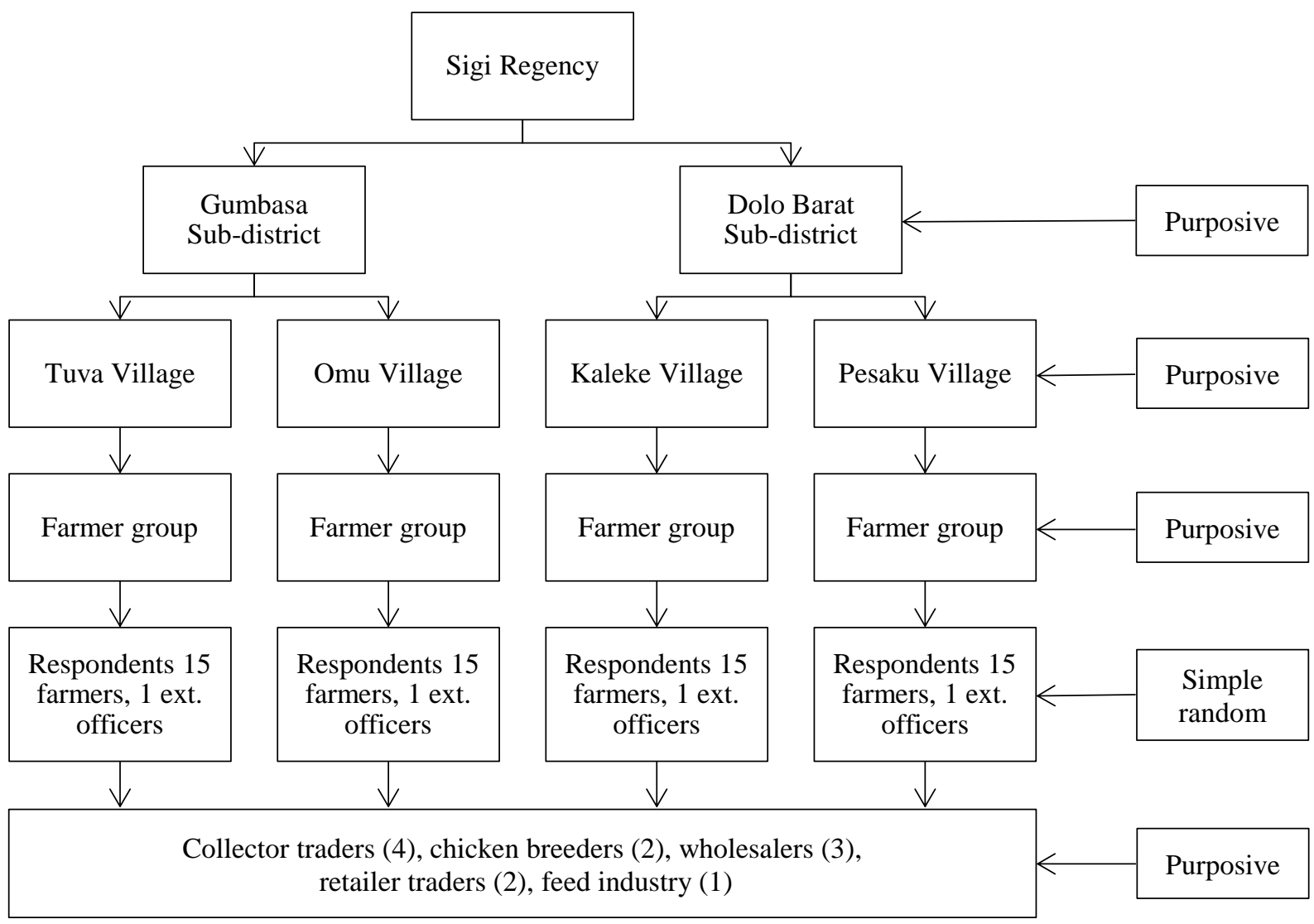

Figure 1. Respondents determination scheme

Data collection was carried out for three months, from October to December 2019. The secondary data were collected from the Central Bureau of Statistics of Central Sulawesi, Provincial Agricultural Service, District Agricultural Service and District Industrial and Commerce Service. The secondary data were corn production, corn productivity and corn development programs.

\section{Method of analysis}

Descriptive and statistical data analysis was performed. The amount of marketing margin obtained referred to the following formula (Sujarwo et al., 2011). 
Where:

$$
\mathrm{MM}=\mathrm{Pr}-\mathrm{Pf}
$$

$$
\begin{array}{ll}
\mathrm{MM} & =\text { Marketing margin } \\
\mathrm{Pr} & =\text { Retail price } \\
\mathrm{Pf} & =\text { Farmer price }
\end{array}
$$

The marketing margin was estimated with the following formula.

Where:

$$
\mathrm{MM}=\mathrm{MC}+\mathrm{B}
$$

$\begin{array}{ll}\text { MM } & =\text { Marketing margin } \\ \text { MC } & =\text { Marketing cost } \\ \text { B } & =\text { Benefit of marketing action }\end{array}$

Distribution of marketing margin is a share of the profits of service marketing agencies that have been allocated to perform marketing functions. The distribution of marketing margin followed the formula.

Where:

$$
\mathrm{Dm}=\frac{\mathrm{M}_{\mathrm{i}}}{\mathrm{M}_{\text {total }}} \times 100 \%
$$

$\mathrm{DM}=$ Distribution of marketing margin

$\mathrm{M}_{\mathrm{i}} \quad=$ Marketing margin $-\mathrm{i}$, market institution $-\mathrm{i}$

$\mathrm{M}_{\text {total }}=\operatorname{Pr}-\operatorname{Pf}\left(\right.$ IDR kg $\left.{ }^{-1}\right)$

The share of the price received by farmers was calculated by the formula.

$$
\text { Shp }=\frac{\operatorname{Pf}}{\operatorname{Pr}} \times 100 \%
$$

Where:

$$
\begin{array}{ll}
\text { Shp } & =\text { Share producer price }(\%) \\
\operatorname{Pr} & =\text { Price in retail/consumer level (IDR } \\
& \mathrm{kg}^{-1} \text { ) } \\
\text { Pf } & =\text { Price in producer level }\left(\text { IDR } \mathrm{kg}^{-1}\right. \text { ) }
\end{array}
$$

The significance of the farmers' share difference was tested using the analysis of variance difference test (ANOVA). The hypotheses used are:

Ho: There is no difference in farmers' share value in each corn marketing channel.

Ha: There is a difference in the farmers' share value in each corn marketing channel.

The ANOVA test statistic is the variance ratio (VR), which is distributed as $F$ with the appropriate number of numerator degrees of freedom and denominator degrees of freedom at the chosen $\alpha$ level. ANOVA analysis used a $95 \%$ confidence interval or a significance level of 0.05 , with formula (Kim, 2014):

$$
\mathrm{VR}=\frac{\text { Among }- \text { group mean square }}{\text { Within }- \text { group mean square }}
$$

A lower value of $\mathrm{F}$ was compared to the significance level of 0.05 , meaning that the null hypothesis was rejected while a higher value was accepted. The ANOVA test was also used to compare the means of three groups of marketing channels.

\section{RESULTS AND DISCUSSION}

Marketing aspects explored in this study include marketing channels, marketing margins, distribution of marketing margin and farmer shares.

\section{Marketing channels}

Products that have been produced must be sold to consumers or end-users to generate financial benefits. Producers distribute their products to consumers using marketing channels. Marketing channels commonly involve the following parties: producers, intermediaries and end-consumers or industrial users (Utomo and Joko, 2009). There are three kinds of marketing channels in the corn market in Sigi Regency Figure 2, 3 and 4.

The first marketing channel for corn in Sigi Regency begins from farmers as producers whose products are directly purchased by consumers without intermediaries. These consumers are limited to breeders around the farmers' surrounding areas, indicating that the producers and consumers have already known each other. The farmer production purchased in this channel is not high and the intermediaries are absent, making the purchase price higher than that of the collector traders. This is in line with the findings of the study by Sudrajat et al. (2014) that the relationship among corn marketing agencies in Tujuh Belas Sub-district, Bengkayang Regency, is based on the implementation of social values and norms that play an important role in increasing the efficiency and effectiveness of the overall marketing institution. Reducing the number of intermediaries in the marketing process is in the interest of both producers and end-consumers. 


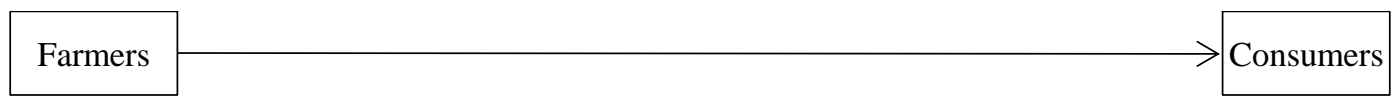

Figure 2. Corn marketing channel I

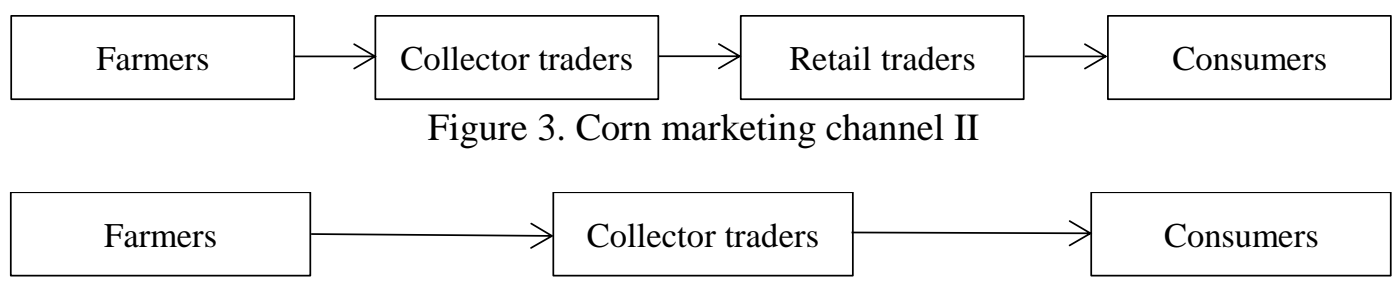

Figure 4. Corn marketing channel III

In the second marketing channel, farmers sell corn to trader collectors in the farm area. Middlemen are commonly present to connect farmers and collector traders. The trader collectors do not only purchase the products but also facilitate the farmers to provide the inputs at an additional cost. However, capital and production facilities used by farmers are obtained by agreement. Furthermore, corn collectors sell the products to retail traders, who then sell them to the end-consumers in kilograms. A mutual bond with specific buyers through the mutual trust shaped overtime in the marketing process is another way to manage price risk (Zidora et al., 2016).

In the third marketing channel, collector traders gather corn from farmers and distribute it to the feed industry of Japfa Comfeed Indonesia Tbk in Palu City, one of the most integrated agri-food companies in Indonesia. The company's business units are the manufacture of animal feed, chicken breeding, poultry processing and agricultural cultivation. From the warehouse of PT. Japfa Comfeed Indonesia Tbk in Palu, the product is then distributed to factories in Makassar, Surabaya, Tangerang, Sragen and Sidoarjo. In line with the opinion of Suryadewi et al. (2018), large traders are in charge of receiving corn supplies from collectors and corn farmers. Marketing functions performed by wholesalers are the exchange, physical and facility function.

Generally, the challenge in product marketing for small farmers is to connect product from producers to consumers in local agriculture. The connection of the production place and consumers place can be linked by a regional network points consolidation. Since the constraints generally created by the need of intermediaries. The capacity of centers play an important role as a solution of distance constraint, or to accommodate farmers that only can reach the nearest area (Kambli and McGarvey, 2020).

\section{Marketing margin}

Marketing margin is the price at the producer level with the price at the final level. Marketing margin is often used as an indicator of marketing efficiency and an indicator of trends in costs, profits and services provided by farmers in the marketing channel (Arumugam and Ibrahim, 2015). The marketing margins in different marketing channels can be ununiform because the values depend on the length of the marketing channels, the activities that have been carried out and the profit expected by the marketing agencies involved in marketing. The corn marketing margins are demonstrated in Table 1.

Table 1. Corn marketing margins in Sigi Regency, Central Sulawesi

\begin{tabular}{|c|c|c|c|}
\hline Channels & $\begin{array}{l}\text { Farmgate price } \\
\left(\text { IDR kg }{ }^{-1}\right)\end{array}$ & $\begin{array}{c}\text { Consumer price } \\
\left.(\text { IDR kg })^{-1}\right)\end{array}$ & $\begin{array}{l}\text { Marketing margin } \\
\left.(\text { IDR kg })^{-1}\right)\end{array}$ \\
\hline Channel I & 3,800 & 3,800 & 0 \\
\hline Channel II & 3,400 & 4,000 & 600 \\
\hline Channel III & 3,400 & 3,700 & 300 \\
\hline
\end{tabular}

Corn marketing in Sigi Regency generally applies three types of marketing channels (Figures 2, 3 and 4). Marketing channel 1 received the lowest margin because consumers purchase the product directly from farmers without involving intermediaries. The consumers in 
this case are the breeders whose businesses are around the farmers' land where transport costs are not high. Channels 3 and 2 have higher margin values, respectively. The longer the marketing channel is, the higher the marketing margin will be. The value of marketing margin cannot be separated from the main actors, recognized as trader collectors or middlemen.

The role of the middleman in the marketing channel influences the marketing margin. The role in the agricultural commodity market in Indonesia

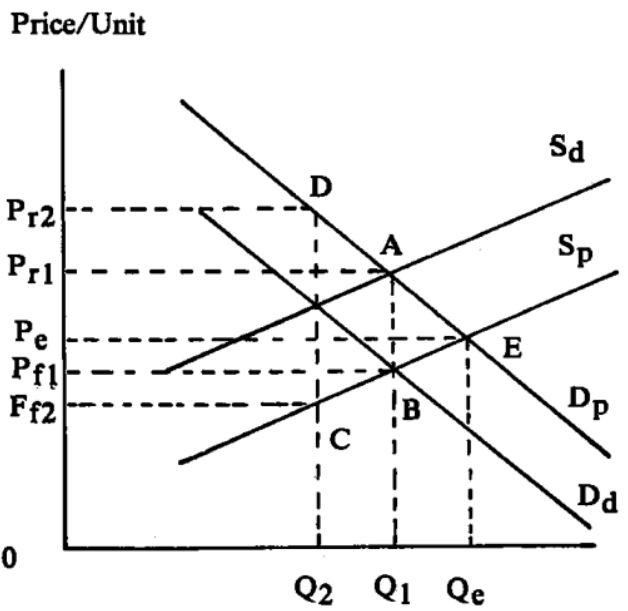

is vital. In general, the marketing costs include transportation, processing, storage, capital and other costs. In providing marketing services, the middleman will generate profits as the payment of their works. The marketing costs and middleman's profits are all calculated as marketing margins. Since the marketing margin will be distributed to both producers and consumers, the price at the farmer level will go down and at the same time, the price at the consumer level will increase, as described in Figure 5.

Figure 5. The concept of middleman role in marketing margin

Source: Hadi, 1990

Two kinds of situations in the corn marketing system are illustrated in Figure 5. The first situation (the left side of Figure 5) happens in channel I, where intermediaries do not exist; and thus, producers directly meet the consumers. The second situation happens in channel II and channel III. In this situation, intermediaries are present and producers do not directly meet the consumers, as presented in the right side of Figure 5.

In channel I (left side of Figure 5), E is the equilibrium point as the intersection of the equilibrium price $(\mathrm{Pe})$ and equilibrium quantity (Qe). There is no marketing margin because the marketing cost is considered zero. An illustration of the situation in channels II and III is demonstrated on the right side of Figure 5. Middlemen or intermediaries decide marketing cost distributed to both producers and consumers. Marketing cost distribution contributes to a decrease in farmgate and an increase in consumer price at the same time. The quantity moves from $\mathrm{Q}_{\mathrm{e}}$ to $\mathrm{Q}_{1}$, while the farmgate goes down from Pe to Pf1.
Some literature reviews suggest that the marketing margin tends to fluctuate in the short run and gets higher in the long run (Tomek and Kaiser, 2014). The marketing margin, characterized as some functions of the difference between retail and farm price of a given farm product, is intended to measure the cost for providing marketing services. Furthermore, Wohlgenant (2001) has stated in his book that the margin is influenced primarily by shifts in retail demand, farm supply and marketing input prices. However, other factors are also important, including time lags in supply and demand, market power, risk, technical change, quality and spatial considerations. Lenou Nkouedjo et al. (2020) have detailed that without applying bleak strategies, informal actors acquire truncated net marketing margins, but with illicit strategies, they will generate high marketing margins that build an unfair system for the formal actors. Therefore, the informal actors should be integrated into the formal actors to play a better function in the marketing channel and the sustainability of the sector. 


\section{Farmers' share}

Farmers' share is the percentage comparison between the price of corn paid by consumers and the price of corn received by farmers. In other words, it is an indication of farmer's acceptance compared to other marketing actors in the marketing chain.

Table 2. Farmer's share of corn marketing in Sigi Regency, Central Sulawesi

\begin{tabular}{cc}
\hline Channel & Farmer's Share (\%) \\
\hline Channel I & 100.00 \\
Channel II & 85.00 \\
Channel III & 91.89 \\
\hline
\end{tabular}

Table 2 shows that the farmer's share of the first channel is $100 \%$ because of the absence of an intermediary. The consumer price is equivalent to the farmer price. However, in the in-field case, this channel is limited on covered area and volume due to marketing cost savings. In the second channel, the farmer's share is $85.00 \%$ with two intermediaries. Meanwhile, the third channel has a $91.89 \%$ farmers' share. Pamungkas et al. (2013) have mentioned that the more intermediary institution or service in the marketing channel is, the smaller the farmers' share will be. Arbi et al. (2018) have also added that the share received by farmers shows the fairness of the outcome distribution by trade collectors, wholesalers and retailers toward farmers. The higher the percentage is, the better and more efficient the marketing system will be (Sondakh et al., 2016).

The results of this study presented in Table 2 depict that the different channels have different farmers' shares reinforced by the results of the statistical analysis using ANOVA. The statistical differences of farmers' shares among channels are presented in Table 3.

Table 3. Statistical significance results of farmer's share on corn marketing in Sigi Regency, Central Sulawesi

\begin{tabular}{lccc}
\hline \multicolumn{1}{c}{ Null hypothesis } & $\begin{array}{c}\text { Significance } \\
\text { level }\end{array}$ & $\begin{array}{c}\text { Anova significance } \\
\text { level }\end{array}$ & Decision \\
\hline $\begin{array}{l}\text { There is no significant difference in } \\
\text { farmer's share in every marketing } \\
\text { channel of the corn market }\end{array}$ & 0.005 & 0.000 & $\begin{array}{c}\text { The null hypothesis } \\
\text { is rejected }\end{array}$ \\
\hline
\end{tabular}

The results of the ANOVA analysis show that each corn marketing channel is significantly different in its farmer's share value. Farmer's share is one indicator of the efficiency in a marketing chain. Higher the farmer's share represents more efficient marketing and a higher portion of farmer's profit. Channel I is the most efficient channel with the highest farmer's share. This is consistent with Wowiling et al. (2019) that the longer the marketing channel is, the greater the marketing margin and vice versa. Moreover, the shorter the marketing channel is, the greater the share received by a farmer and vice versa.

The agreed price of the seller and the buyer is based on bargaining, while the method of payment of the buyer for the agreed price can be in immediate cash payment or installment. Some of the efforts that can be made to improve marketing efficiency are to build a strong farmer institution and support farmers' entrepreneurship especially in commodity services and marketing (Riyadh, 2018). Whenever the average cost is still relatively smaller compared to the difference in price obtained by each marketing channel, farmers can allocate costs incurred to produce maximum output (Muhaimin et al., 2019).

Marketing cost decided by intermediaries is one of farmer share's determination factors. It is pointed out by Abokyi et al. (2020) that age, gender, market access, the role of extension services and marketing costs, including transport and packaging costs, are the aspects that guide the participation (share) of smallholder farmers in Ghana. All factors serve as the sources for government to develop interventions to stabilize and grow income for smallholder corn farmers.

In a highly competitive market, adding value is also important to generate more income, including in the market channel. Kyomugisha et al. (2018) have found that adding value to the potato on-farm contributes to farmers' relatively higher income. Farmers receive $25 \%$ higher income when they add value to the produce. Selling products to local rural traders is more efficient than selling to other options in 
market chains. Finally, they recommend farmers add value, join collective/contractual marketing and sell the product directly to the nearest marketing actor in the chain. Another example is adding the value of a household to obtain net additional profitability by using a storage bag. Farmers' decision to use storage bags is influenced by several factors, such as access to information, the initial cost and the storage capacity of the technology. Thus, increasing awareness and improving supply chain efficiency to reduce the cost of the storage bags will improve adoption rates (Alemu et al., 2021).

In some cases, a big retailer has decided a margin for a consumer product from a supplier before the supplier determines the margin. It is reflected a power shift from upstream supplier to downstream retailer in the supply chain. By delaying decision-making, the latemoving members can make a more precise conclusion on the cost by observing the margin demanded by the early-movers and therefore, they choose a more desirable margin (Matsui, 2019).

One marketing agreement in a formal way is price plus contract, which is an agreement to reimburse a company for incurred expenses plus a specific amount of profit, usually stated as a percentage of the contract's full price. Elliott et al. (2020) have found that the price plus contracts had good achievement in 2008-2017, gaining the best bushel price and the highest average sharpe ratio for both corn and soybean. The price plus contract presents corn and soybean producers with the best risk-adjusted return to boundary production during 2008-2017.

Mexico has protected agricultural commodities by using the coverage program of the Bureau of Market Services and Agricultural Market Development (ASERCA). It is a means used by corn producers to purchase derived products. The Mexican producers have faced high volatility of corn prices. Thus, the domestic prices of corn should be adjusted as an incentive for Mexican producers to participate in the program (Arango et al., 2017). Another way for increasing production and improving the market chain to agricultural products is integration in all sectors. For example, in the sheep market, many actors (sheep farms or producers, marketers, processors, barbacoa sellers and consumers) are involved in the sheep market chain, as well as the investigators, technicians and governmental sectors. There is a need for integration to achieve strategies that Mondragón-Anselmo et al. (2012) contribute to the improvement of sheep meat production.

\section{CONCLUSIONS}

The longer marketing channel contributes to a higher marketing margin but lower farmer's share. It is reinforced by the results of the significant difference test that confirm a significant difference in farmer's share value in each marketing channel. The shortest marketing channel with zero intermediaries is confirmed as the best choice. Therefore, it is recommended that farmers shorten the marketing chain and strengthen their bargaining position by activating groups. Meanwhile, the government can play an active role to help farmers get access to strengthening capital and marketing.

\section{ACKNOWLEDGEMENT}

The authors would like to thank Dr. Ir. Fery Fahruddin Munier, M.Sc., the Head of Central Sulawesi Assessment Institute for Agricultural Technology (AIAT), for supporting this study.

\section{REFERENCES}

Abokyi, E., Strijker, D., Asiedu, K. F., \& Daams, M. N. (2020). The impact of output price support on smallholder farmers' income: evidence from maize farmers in Ghana, Heliyon, 6(9), E05013. https://doi.org/10.1016 /j.heliyon.2020.e05013

Alemu, G. T., Nigussie, Z., Haregeweyn, N., Berhanie, Z., Wondimagegnehu, B. A., Ayalew, Z., Molla, D., Okoyo, E. N., \& Baributsa, D. (2021). Cost-benefit analysis of on-farm grain storage hermetic bags among small-scale maize growers in northwestern Ethiopia. Crop Protection, 143, 105478. https://doi.org/10.1016/j.cropro.2020.105478

Anindita, B., Baladina, N., \& Setiawan, B. (2013). Effect of marketing efficiency improvement in Indonesia. Russian Journal of Agricultural and Socio-Economic Sciences, 7(19), 13-21. http://dx.doi.org/10.18551/rjoas.2013-07.02

Arango, A., Guzmán, M., \& Nelly, A. (2017). Transmission of future prices of corn of the Chicago Board of Trade to the Mexican spot market. Contaduría y Administración, 
62(3), 941-957. https://doi.org/10.1016/j.cya. 2017.05.003

Arbi, M., Thirtawati, \& Junaidi, Y. (2018). Analisis saluran dan tingkat efisiensi beras semi organik di Kecamatan Rambutan Kabupaten Banyuasin. Jurnal Sosial Ekonomi Pertanian, 11(1), 22-32. https://doi.org/ 10.19184/jsep.v11i1.7151

Arumugam, N., \& Ibrahim, R. (2015). An exploration on corn industry marketing channels. Journal of Agrobiotechnology, 6(1), 33-50. Retrieved from https://journal.unisza. edu.my/agrobiotechnology/index.php/agrobio technology/article/view/79

BPS-Statistic of Sulawesi Tengah. (2019). Sulawesi Tengah Province in Figures 2019. Retrieved from https://sulteng.bps.go.id/ publication/2019/08/16/db05cef887cda1380a 8829af/provinsi-sulawesi-tengah-dalam-angk a-2019.html

Elliott, L., Elliott, M., Slaa, C. T., \& Wang, Z. (2020). New generation grain contracts in corn and soybean commodity markets. Journal of Commodity Markets, 20, 100113. https://doi. org/10.1016/j.jcomm.2019.100113

Hadi, P. U. (1990). Analysis of market margin behaviour using econometric model. Jurnal Agro Ekonomi, 9(1), 26-40. Retrieved from http://ejurnal.litbang.pertanian.go.id/index.ph p/jae/article/view/4976

Kalangi, J. K. J., \& Umboh, S. J. K. (2017). Impact of margin of feed price changes on the production and income small-holding broiler farms in Indonesia. IOSR Journal of Agriculture and Veterinary Science, 10(10), 35-41. https://doi.org/10.9790/2380-1010013 541

Kambli, A., \& McGarvey, R. G. (2020). Network design for local agriculture using robust optimization. Information Processing in Agriculture. https://doi.org/10.1016/j.inpa.20 20.09.004

Kim, H.-Y. (2014). Analysis of variance (ANOVA) comparing means of more than two groups. Restorative Dentistry \& Endodontics, 39(1), 74-77. https://doi.org/ 10.5395/rde.2014.39.1.74

Kyomugisha, H., Sebatta, C., \& Mugisha, J.
(2018). Potato market access, marketing efficiency and on-farm value addition in Uganda. Scientific African, 1, e00013. https://doi.org/10.1016/j.sciaf.2018.e00013

Lenou Nkouedjo, L., Mathe, S., Fon, D. E., Geitzenauer, M., \& Awah Manga, A. (2020). Cocoa marketing chain in developing countries: How do formalinformal linkages ensure its sustainability in Cameroon? Geoforum, 117, 61-70. https:// doi.org/10.1016/j.geoforum.2020.09.005

Martínez-Castillo, R. (2016). Sustainable agricultural production systems. Tecnología en Marcha, 29(Suppl. 1), 70-85. Retrieved from https://www.scielo.sa.cr/pdf/tem/v29s1/03793982-tem-29-s1-70.pdf

Matsui, K. (2019). A supply chain member should set its margin later if another member's cost is highly uncertain. European Journal of Operational Research, 275(1), 127-138. https://doi.org/10.1016/j.ejor.2018.11.027

Mondragón-Anselmo, J., Dominguez-Vara, I. A., Rebollar-Rebollar, S., Bórquez-Gastelum, J. L., \& Hernández-Martínez, J. (2012). Margins of sheep meat marketing in Capulhuac, State of Mexico. Tropical and Subtropical Agroecosystems, 15(1), 105-116. Retrieved from https://www.revista.ccba.uady.mx/ojs/ index.php/TSA/article/view/888

Muhaimin, A. W., Yapanto., L. M., \& Wijayanti, V. (2019). Analysis of market structure, conduct and performance of corn (Zea mays L.) in Kedung Malang Village, Papar District, Kediri Regency, East Java. International Journal of Civil Engineering and Technology (IJCIET), 10(6), 10-16. Retrieved from https://iaeme.com/MasterAdmin/Journal_uplo ads/IJCIET/VOLUME_10_ISSUE_6/IJCIET _10_06_035.pdf

Okpiaifo, G., Durand-Morat, A., West, G. H., Nalley, L. L., Nayga, R. M., \& Wailes, E. J. (2020). Consumers' preferences for sustainable rice practices in Nigeria. Global Food Security, 24, 100345. https://doi.org/ 10.1016/j.gfs.2019.100345

Pamungkas, D., Pujiharto, \& Watemin. (2013). Analisis pemasaran jagung (Zea mays L.) di Desa Karangmalang Kecamatan Kedungbanteng Kabupaten Tegal. 
AGRITECH, 18(2), 101-106. Retrieved from http://jurnalnasional.ump.ac.id/index.php/AG RITECH/article/view/1743

Rahayu, H. S., \& Suwitra, I. K. (2019). Dinamika produktivitas komoditas pangan utama Sulawesi Tengah dalam dinamika program percepatan swasembada pangan. Prosiding Seminar Nasional Fakultas Pertanian UNS, 3(1), 89-96. Retrieved from https://jurnal.fp. uns.ac.id/index.php/semnas/article/view/1412

Rigby, D., \& Caceres, D. (1997). The sustainability of agricultural systems. In Rural Resources, Rural Livelihoods Working Paper series, Working Paper No. 10. Manchester, UK: Institute for Development Policy and Management, University of Manchester. Retrieved from http://www.sed.man.ac.uk/ idpm/research/publicatios/wp/rr/documents/rr _wp10.pdf

Riyadh, M. I. (2018). Analisis saluran pemasaran lima pangan pokok dan penting di lima kabupaten Sumatera Utara. Jurnal Ekonomi \& Kebijakan Publik, 9(2), 161-171. http://dx.doi. org/10.22212/jekp.v9i2.1075

Rosmawati, H. (2011). Analisis efisiensi pemasaran pisang produksi petani di Kecamatan Lengkiti Kabupaten Ogan Komering Ulu. Agronobis, 3(5), 1-9. Retrieved from https://scholar.google.com/ scholar?cluster $=3872997678526359660 \& \mathrm{hl}=$ en\&as_sdt $=2005 \&$ sciodt $=0,5$

Sondakh, J., Rauf, A., Rembang, J., \& Sudarti. (2016). Analisis produksi dan rantai pemasaran jagung di Kabupaten Minahasa Selatan Provinsi Sulawesi Utara. Jurnal Pengkajian dan Pengembangan Teknologi Pertanian, 19(3), 213-226. http://dx.doi.org/ 10.21082/jpptp.v19n3.2016.p213-226

Suarni, S., \& Yasin, M. (2011). Jagung sebagai sumber pangan fungsional. Iptek Tanaman Pangan, 6(1), 41-56. Retrieved from http:// ejurnal.litbang.pertanian.go.id/index.php/ippa n/article/view/2595

Sudrajat, J., Mulyo, J. H., Hartono, S., \& Subejo. (2014). Analisis efisiensi dan kelembagaan pemasaran jagung di Kabupaten Bengkayang. Jurnal Social Economic of Agriculture, 3(1), 14-23. http://dx.doi.org/10.26418/j.sea.v3i1.7 702
Sujarwo, Anindita, R., \& Pratiwi, T. I. (2011). Analisis efisiensi pemasaran jagung (Zea mays L.) (Studi kasus di Desa Segunung Kecamatan Delanggu, Kabupaten Mojokerto). Agrise, 11(1), 56-64. Retrieved from https://agrise.ub. ac.id/index.php/agrise/article/view/57

Sulaiman, A. A., Kariyasa, I. K., Hoerudin, Subagyono, K., \& Bahar, F. A. (2017). Cara cepat swasembada jagung. Jakarta: IAARD Press. Retrieved from https://press.litbang. pertanian.go.id/index.php/item/kategori/bukudiseminasi/59-cara-cepat-swasembadajagung.

Suryadewi, A., Rahayu, E. S., \& Setyowati. (2018). Efisiensi pemasaran jagung di Kabupaten Sragen. Agrista, 6(1), 17-25. Retrieved from https://jurnal.uns.ac.id/agrista/ article/view/31074

Tomek, W., \& Kaiser, H. (2014). Agricultural Product Prices (5th ed.) Ithaca, NY: Cornell University Press. https://doi.org/10.7591/978 0801471117

Utomo, \& Joko, T. (2009). Fungsi dan peran bisnis ritel dalam saluran pemasaran. Fokus Ekonomi : Jurnal Ilmiah Ekonomi, 4(1), 4455. Retrieved from https://ejournal.stiepena. ac.id/index.php/fe/article/view/50

Wohlgenant, M. K. (2001). Chapter 16 Marketing margins: Empirical analysis. In B. L. Gardner, G. C. Rausser (Ed.), Handbook of Agricultural Economics, vol. 1, Part 2, pp. 933-970. Amsterdam, Netherland: Elsivier. https://doi. org/10.1016/s1574-0072(01)01007-6

Wowiling, C. C., Pangemanan, L. R. J., \& Dumais, J. N. K. (2019). Analisis pemasaran jagung di Desa Dimembe Kecamatan Dimembe Kabupaten Minahasa Utara. AgriSosioekonomi, 14(3), 305-314. https:// doi.org/10.35791/agrsosek.14.3.2018.22326

Zidora, C. B. M., da Cunha, C. A., Wander, A. E., \& de Oliveira, O. J. (2016). Price risk management strategies in corn marketing in rural Mozambique. Research Journal of Agriculture and Environmental Management, 5(1), 160-171. Retrieved from https://www. researchgate.net/publication/309847051_Pric e_risk_management_strategies_in_corn_mark eting_in_rural_Mozambique 